\title{
The Influence of Apparatus Competence and Organizational Commitment on the Quality of Village Funds Financial Reports
}

\author{
Puji Rahayu ${ }^{1}$, Hari Setiyawati ${ }^{2}$ \\ \{prahayu.sembada@gmail.com ${ }^{1}$, hari_setiyawati@mercubuana.ac.id ${ }^{2}$ \} \\ Department of Accounting, Universitas Mercu Buana Jakarta, Indonesia ${ }^{12}$
}

\begin{abstract}
The government authorizes the Village to manage their resources to improve the economy and welfare of the community, requiring village apparatus to have an understanding and commitment to the preparation of financial reports in accordance with [1] Government Regulation number 71/2010 on Government Accounting Standards. This study aims to analyze the effect of the Village Apparatus Competence and Organizational Commitment on the Quality of Village Funds Financial Reports. This research was conducted at villages in Sukabumi Regency, West Java, which involved the Village Head as one of the Village Fund Management Apparatuses as the observation unit with 193 villages as the research samples. The obtained data were analyzed by using SEM models and processed using Smart PLS software. The results of this study revealed that the competence of the apparatus significantly influences the quality of Village Fund reports and organizational commitment does not greatly affect the quality of Village Fund reports.
\end{abstract}

Keywords: Village Fund, Apparatus Competence, Quality of Village Fund Report

\section{Introduction}

[2] Law No. 6 of 2014 concerning Villages sets villages at the forefront of development and improvement of community welfare. Villages are given the authority and adequate funding sources to manage their potential in enhancing the economy and welfare of the community. The government has provided a big amount of money for the villages in the form of Village Funds. The village funds aim to enhance public services in the village, alleviate poverty, improve the village economy, overcome disparities between villages, and strengthen rural communities as the subject of development. In 2015 budgeted at Rp. 20.7 trillion with an average of Rp. 280 million per village, in 2016 increased to Rp. 46.98 trillion with an average of Rp. 628 million per village, in 2017 increased to Rp. 60 Trillion with an average of $\mathrm{Rp} 800$ million per village [3].

Researchers conducted research on villages in Sukabumi Regency, West Java because Sukabumi Regency has the largest area and the largest number of villages in West Java. Based on the data of the Central Statistics Agency of Sukabumi Regency in 2018, the average village funds received were around Rp. 800 million per village. The important aspect in managing Village Funds is an understanding of Village Fund management that must be comprehended by the village apparatus to achieve transparency and accountability of village finances through the planning of Village Fund financial reports under Government 
Regulation of the Republic of Indonesia number 71 of 2010 concerning Government Accounting Standards. Solong (2020) stated that competence is a basic characteristic of an individual that influences the way of thinking and acting, making generalizations about all situations encountered in doing work. Mary Ann Von Glinow \& McShane (2008) explained that organizational commitment is related to an employee's emotional that is identical to the involvement in specific organizational activities.

Financial reports require to have qualitative characteristics to provide useful information to its users. Government Regulation of the Republic of Indonesia Number 71 of 2010 concerning Government Accounting Standards requires the quality of government financial statements to have normative requirements that are relevant, have predictive value, complete and punctual. Research by Umar, Usman, \& Purba (2018) revealed that human resource competence has a positive and significant impact on the quality of village funds financial reports. Thenikusuma \& Muis (2019) stated the human resources competence has a positive and significant partially effect on the quality of financial report at Social Agency Bantaeng Regency. Setiyawati \& Iskandar (2020) stated the internal accountant competence had a significant positive effect on the quality of financial reporting, especially in local governments. Tambingon, Yadiati, \& Kewo (2018) stated that the influence of apparatus commitment the role of internal audit of the quality of accounting information systems and their impact on the quality of financial statement.

Silalahi \& Sinambela (2017) stated the commitment organization can influence the quality of government financial report Sumaetara in the province north. Marina, Rura, \& Tawakkal (2018) stated the organizational commitment can moderate the effect of competence of human resources and the use of information technology on the quality of financial report. According to the aforementioned background, the formulation of the problems in this study are 1) Does the competency of the apparatus have a significant effect on the quality of the financial reports? 2) Does organizational commitment significantly influence the quality of financial reports? The purpose of this study is to discover and obtain empirical evidence of the research and to contribute theories, practices, and policies on the influence of apparatus competence and organizational commitment to the quality of the Village Fund's financial reports.

\subsection{Literature Review}

\subsubsection{Apparatus Competence}

Apparatus competence is the skills, knowledge, expertise and good behavior possessed by officials in a particular field to do well-performed works. Busro (2018) and Sutrisno (2017) stated that the competence of the apparatus is the skills, knowledge, expertise, and good behavior possessed by the apparatus in a particular field so that they can perform well in their works. According to Hamsani (2020) competence consists of knowledge obtained from learning outcomes, while skills are a person's ability to perform an activity, a selfconcept that is reflected in one's attitude and physical characteristics in response to a situation or information.

\subsubsection{Organizational Commitment}

Kusumaputri (2018) defined organizational commitment as an individual's level of willingness to maintain membership because of their conformity and interest in the goals and values of the organization. The employee's loyalty to the company and the desire to work hard in supporting the organization, can lead to positive results and stay in the organization. Organizational commitment is an individual's willingness to obey all organizational rules to 
achieve the organization's goals. Nawab \& Bhatti (2011) in Mustarida, Purba, Setiawan, \& Rumondang (2020) states that organizational commitment is defined to the extent that employees recognize the organization that hires them with attachment to the organization.

\subsubsection{Quality of Village Fund Financial Reports}

According to Kertahadi, Sinaga, Syamsul, Siregar, \& Wahyuni (2019) the financial report is the main media for entities to deliver financial information by management to the stakeholders. Financial reports aim to provide financial information that is useful for economic decision making. To provide a financial report that beneficial information for its users, normative requirements must be performed in its preparation, which has to be relevant, reliable, and comparable. Sululing (2018) mentioned that Village Fund's financial report is a statement that shows the financial position for one fiscal year which consists of Village Budget (APBDes), Budget Realization Report (LRA), Village's Initial Wealth Report, Village Balance Sheet and Notes to Village Financial Reports (CALKDes). Research conducted by Nurlis \& Yadiati (2017), Karsan \& Agung (2017), and Synthia (2017) concluded that human resource competence influences the quality of financial statements.

\subsubsection{Conceptual Framework}

Regional Autonomy in Indonesia requires each region to regulate and manage its delegation of government and the local community. Law Number 6 of 2014 concerning Villages is an embodiment of government protection for villages which is the forefront of the national government system. This is actualized by the allocation of the State Revenue and Expenditure Budget designated for villages that are transferred through the Regency/City Regional Revenue and Expenditure Budget and are used to finance government administration, implement community development, and community empowerment. The Village Fund aims to improve public services in the village, alleviate poverty, enhance the village economy, tackle development disparities between villages, and strengthen rural communities as the subject of development. In managing the finances of the Village Fund, the village government must have the quality of human resources supported by accounting education background, frequently attend education and training, and have experience in finance so that it can present financial reports and improve village government performance.

The result of studies conducted by Shintia \& Erawati (2017), Lasmara \& Rahayu (2016), Nurlis \& Yadiati (2017), Darwanis (2016), Karsan \& Agung (2017), Umar et al. (2018), Agung \& Gayatri (2018), Setiyawati (2013), Hertati (2015), Nasution, Supriana, \& Dalimunthe (2018), Indriasih (2014), Nirwana \& Haliah (2018) revealed human resource competence has a positive effect on the quality of financial statements, which means that the more competent human resources are, the better quality of financial statements will be generated. Research conducted by Setiyawati (2013), Tambingon et al. (2018), Silalahi \& Sinambela (2017), Marina Palimbong et al. (2018), and Widari \& Sutrisno (2017) concluded that organizational commitment positively influences the quality of financial statements. In addition, Carsten \& Spector in Dodopo, Sondakh, \& Tinangon (2017) showed that the higher organizational commitment will have an impact on employees to stay in the organization and will always improve their performance. However, some researchers revealed different results. Astika \& Yasa (2018), Pranata (2019), and Oktavia \& Rahayu (2019) stated the result of their researches that organizational commitment does not affect the quality of financial statements.

The relation between apparatus competence and organizational commitment to the quality of the Village Fund's financial reports can be described as follows: 


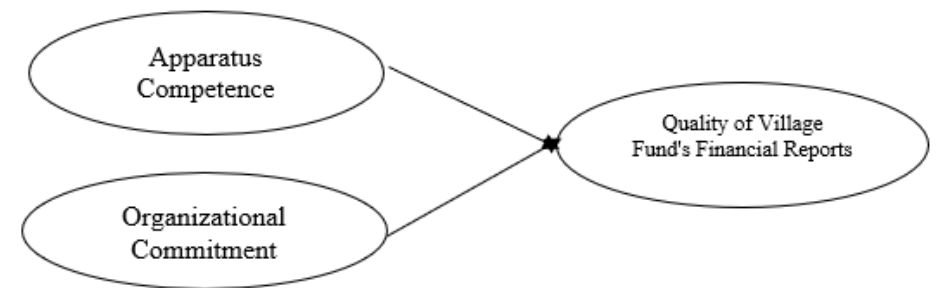

Fig 1. Conceptual Framework

\subsubsection{Hypothesis}

Based on the conceptual framework, the hypotheses used in this study are as follows:

H1: Apparatus Competence significantly influences the quality of Village Fund Reports.

H2: Organizational Commitment has significant effects on the quality of Village Fund Reports.

\section{Research Method}

This research is a quantitative study that used a causality approach to examine the effect of apparatus competence (X1) and organizational commitment (X2) on the quality of village financial reports (Y). The survey was conducted in villages in Sukabumi Regency - West Java, considering that Sukabumi District has the most extensive area and the greatest number of subdistricts in West Java. According to the data from the Central Bureau of Statistics of Sukabumi Regency in 2018, the average Village Fund received is Rp 800 million per village. The population of this research was the Village Fund recipients in Sukabumi Regency, West Java in 2018, which involved 372 villages and 193 villages as the sample research. The sampling technique used is nonprobability where the findings from the research samples cannot be generalized with certainty to the population, Sekaran \& Bougie (2017).

To collect the data, this research used field research through questionnaires and literature studies. In analyzing the data, this study applied the Partial Least Square (PLS) approach which included variable descriptions, validity and reliability tests, structural models of goodness of fit (outer models), and hypothesis testing by using structural equation modeling (SEM) with modeling path partial least square method (PLS) Ghozali (2019). The apparatus competency has a dimension that consists of knowledge, skills, and self-concept. Organizational commitment has a dimension that consists of affective commitment, continuance commitment, and normative commitment. However, the quality of the financial report's variable has dimensions that consist of relevance, reliability, and comparability.

\section{Results and Discussion}

\subsection{Research Variables Description}

The results of the descriptive analysis of each variable are as follows:

Table 1. Variable Descriptions

\begin{tabular}{clc}
\hline No. & Variable & Average Value \\
\hline 1. & Apparatus Competence & 4.09 \\
2. & Organizational Commitment & 3.74 \\
3. & Quality of the Village Fund's financial Reports & 4.28 \\
\hline
\end{tabular}


The table shows that the apparatus competency variable has an average value 4.09 which can be explained that the apparatus competency variable in the villages of Sukabumi Regency can be categorized excellent because the village apparatus has the competency to do their job. The variable organizational commitment shows an average value of 3.74 , indicating that organizational commitment in the villages of Sukabumi Regency is in a good category. This result indicates that the village apparatus possesses awareness and concern for the company's reputation and have a willingness to stay in the company. Meanwhile, the quality of the Village Fund's financial reports variable obtains an average value of 4.28 which means that the quality of the Village Fund's financial reports in the villages of Sukabumi Regency is in an excellent category.

The result also reveals that it has relevant benefits to the budget and source of funds that punctually and completely prepared according to the standard, neutrally presented, honest and verifiable, and consistent with the policy and internally comparable.

\subsection{Validity and Reliability Test}

The following picture is the result of the output loading factor from the construct of the Apparatus Competence, Organizational Commitment, and the Quality of the Village Fund Financial Reports in the Smart PLS application:

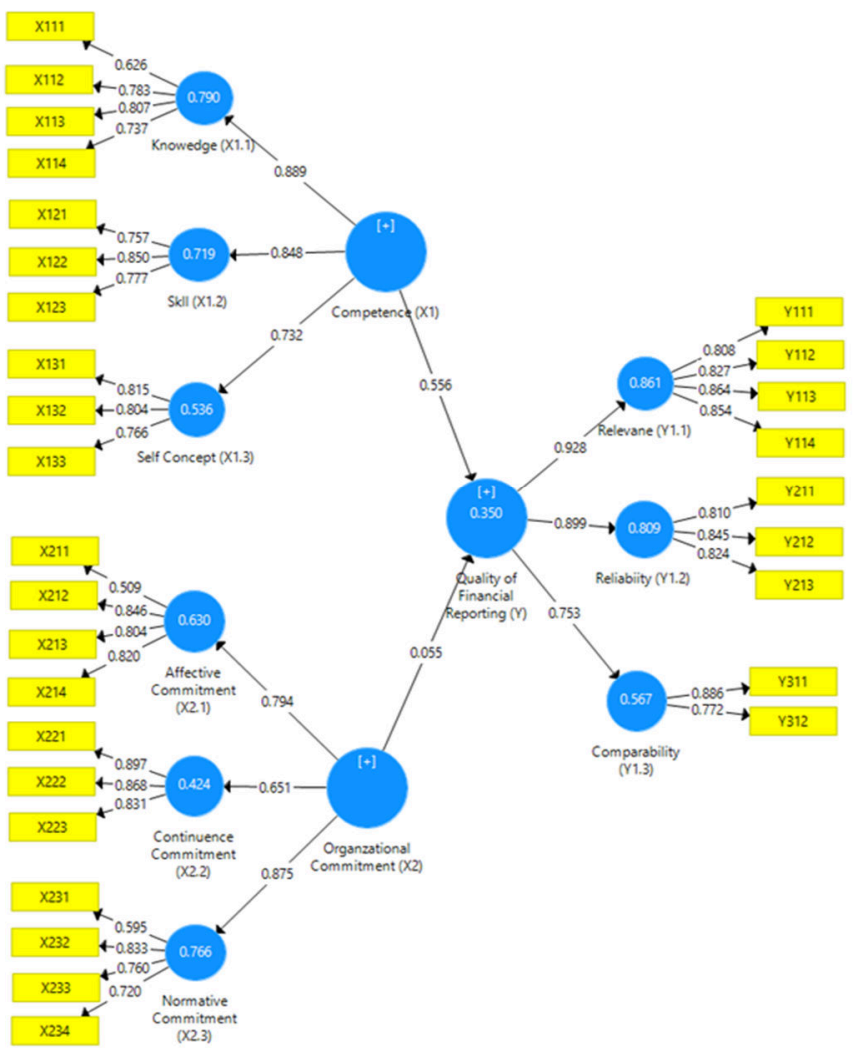

Fig 2. Path analysis and hypothesis testing 
According to the output in the path diagram above, the loading factor for each construct fulfills the convergent validity, which the indicator value is $>0.5$. All loading factors are significant at the $5 \%$ level. The following table is the result of reliability testing on each dimension on the latent variables of the apparatus competence, organizational commitment, and the quality of the Village Fund's financial reports.

Table 2. Reliability Test Cronbach's Alpha dan Composite Reliability

\begin{tabular}{ccc}
\hline Variable/Dimension & $\begin{array}{c}\text { Cronbach's } \\
\text { Alpha }\end{array}$ & $\begin{array}{c}\text { Composite } \\
\text { Reliability }\end{array}$ \\
Apparatus Competence (X1) & 0.839 & 0.874 \\
Knowledge (X1.1) & 0.723 & 0.829 \\
Skills (X1.2) & 0.709 & 0.838 \\
Self Concept (X1.3) & 0.711 & 0.838 \\
Organizational Commitment (X2) & 0.820 & 0.860 \\
Affective Commitment (X2.1) & 0.733 & 0.839 \\
Continuence Commitment (X2.2) & 0.833 & 0.900 \\
Normative Commitment (X2.3) & 0.705 & 0.820 \\
Quality of the Village Fund's Financial Reports (Y) & 0.890 & 0.912 \\
Relevance (Y.1) & 0.859 & 0.904 \\
Andal (Y.2) & 0.768 & 0.866 \\
Comparability (Y.3) & 0.560 & 0.816 \\
\hline
\end{tabular}

According to the output of reliability results above, the dimensions are comparable if it has Cronbach's alpha below 0.60 . Due to the composite reliability value above 0.70 , it is still considered as sub-marginal and concluded that each variable has good reliability or can measure the construct.

\subsection{Evaluation of Structural Goodness of Fit Model (Inner Model)}

Evaluation of the goodness of fit of the research model is measured by using the value of R-Square (R2). R-Square (R2) value at the PLS output. The table below shows the results of the coefficient of determination analysis of the research variables.

Table 3. R Square

\begin{tabular}{cc}
\hline Variable & R Square \\
Quality of the Village Fund's Financial Reports (Y) & 0.350 \\
\hline
\end{tabular}

The table presents that the Quality of the Village Fund's Financial Reports can be explained by Apparatus Competence and Organizational Commitment for 35\% and other variables can be explained outside this study.

\subsection{Hypothesis testing}

The hypothesis testing in this study is based on the results of the Partial Least Square output and use a 5\% significance level. The following figure explains the path diagram for the results of the testing hypothesis: 


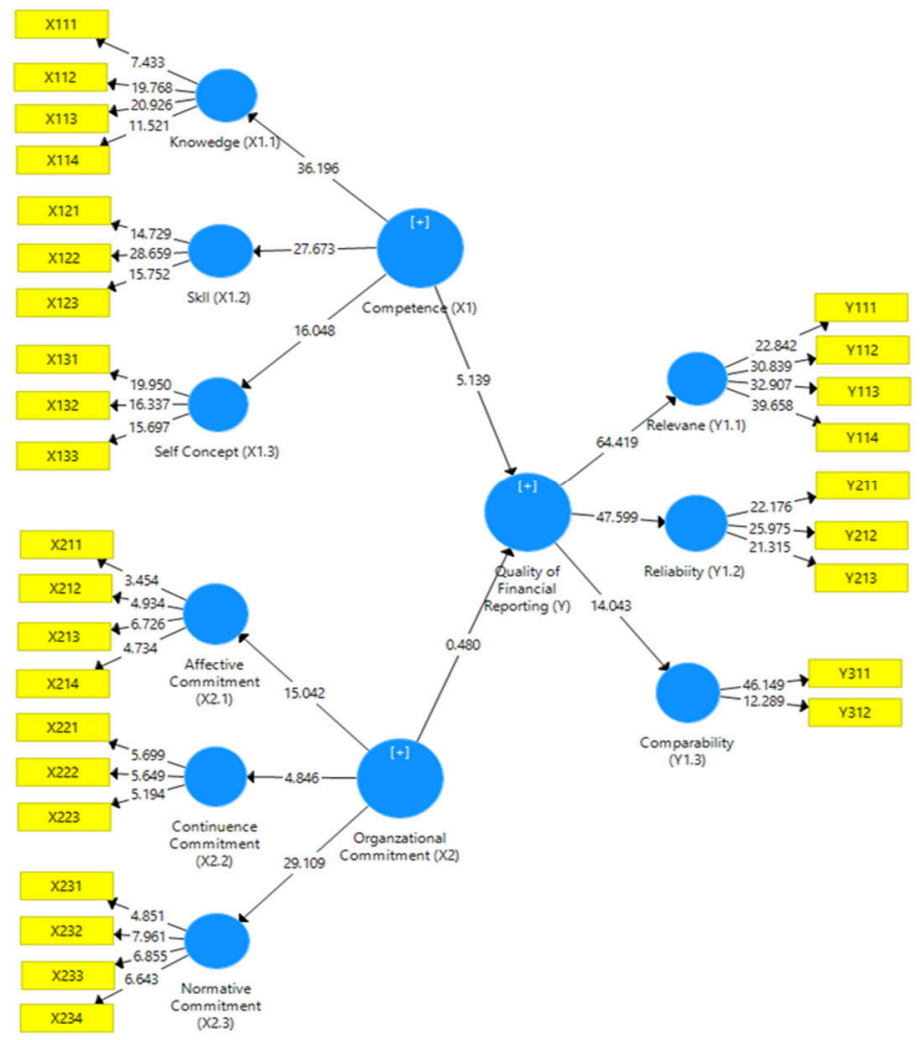

Fig 3. Path Diagram of Hypothesis Testing

The influence of exogenous latent variables to endogenous latent variables is presented in the following table:

Table 4. Hypothesis Testing Result

\begin{tabular}{ccccc}
\hline Influence Between Variables & $\begin{array}{c}\text { Parameter } \\
\text { Coefficient }\end{array}$ & T statistic & P Value & Note \\
\hline $\begin{array}{c}\text { Apparatus Competence } \rightarrow \text { Quality of } \\
\text { the Village Fund's Financial Reports }\end{array}$ & 0.556 & 5.139 & 0.000 & Significant \\
$\begin{array}{c}\text { Organizational Commitment } \rightarrow \text { Quality } \\
\text { of the Village Fund's Financial Reports }\end{array}$ & 0.055 & 0.480 & 0.632 & Insignificant \\
\hline
\end{tabular}

In testing the first hypothesis, the value of the parameter coefficient obtained from the effect of the apparatus competence towards the quality of the Village Fund financial reports is 0.556 with a statistical value of $5.139>1.981$ which indicates that there is a significant influence of the apparatus competence on the quality of the Village Fund's financial reports. The result of this hypothesis in accordance with the first hypothesis in which apparatus competence significantly influence the quality of the Village Fund's financial reports.

The value of the parameter coefficient in the second hypothesis gained from the influence of organizational commitment to the accountability of the Village Fund management is 0.055 
with Tstatistic value $0.632<1.981$ which means that there is no significant effect of organizational commitment to the quality of the Village Fund's financial reports. The results of this study do not correspond with the second hypothesis that there is a significant influence of organizational commitment to the quality of the Village Fund's financial reports.

\subsection{Discussion}

The apparatus competence has a significant effect on the quality of the Village Fund's financial reports. The competence of the village apparatus is reflected in the knowledge, skills, and self-concept possessed by the village apparatus in Sukabumi Regency in preparing financial reports. Normative requirements required to generate financial reports that can achieve the desired quality as stated in Government Regulation of the Republic of Indonesia Number 71 of 2010 concerning Government Accounting Standards, which are relevant, reliable, and comparable. The results of this study are in line with a theory by Busro (2018) which stated that competence is everything a person has in the form of knowledge, skills, and other individual factors to be able to perform a task.

Moreover, Sutrisno (2017) also stated that competence is a behavioral dimension of a staff or company leadership which consists of expertise, skill, knowledge, and an excellent attitude. This research is in line with the previous studies conducted by Shintia \& Erawati (2017), Lasmara \& Rahayu (2016), Nurlis \& Yadiati (2017), Darwanis (2016), Karsan \& Agung (2017), Umar et al. (2018), Agung \& Gayatri (2018), Setiyawati (2013), Hertati (2015), Nasution, Supriana, \& Dalimunthe (2018), Indriasih (2014), Nirwana \& Haliah (2018) which mentioned that human resource competence has a positive effect on the quality of financial reports, which means that the more qualified human resources they have, the better the quality of financial statements they will create.

Organizational commitment does not significantly influence the quality of the Village Fund's financial statements. The village apparatus in Sukabumi Regency has a high commitment to the organization which is acknowledged from the level to serve and engage in company activities. Most of the village apparatus feel proud of the company, have an attachment, comfort, and readiness in conducting the required tasks. Furthermore, they also possess awareness and concern towards the company's reputation which leads to the willingness to stay in the company. However, the level of organizational commitment does not affect the quality of the Village Fund's financial reports in Sukabumi Regency. This research is in line with Astika \& Yasa (2018), Pranata (2019), and Oktavia \& Rahayu (2019) which revealed that organizational commitment does not affect the quality of financial reports. Fitriana \& Hoesada (2019) stated organizational commitment does not significantly influence the quality of financial reporting.

This study is not in line with Setiyawati (2013), Tambingon et al. (2018), Silalahi \& Sinambela (2017), Marina Palimbong et al. (2018), and Widari \& Sutrisno (2017) which revealed that organizational commitment has a positive influence on the quality of financial statements. Carsten and Spector in Dodopo, Sondakh, \& Tinangon (2017) exposed that the higher organizational commitment will have an impact on employees to stay in the organization and they will always improve their work performance. This means that high employee performance will produce high-quality financial reports. 


\section{Conclusions}

According to the results of data analysis and discussion, the study revealed that the competence of the apparatus significantly influences the quality of the Village Fund's financial statements, and organizational commitment does not have a significant influence on the quality of the Village Fund's financial statements. The village apparatus in Sukabumi Regency has not possessed a concern for the quality of the Village Fund's financial reports. The residents give the full trust of the assigned village apparatus because it has been accompanied by a Village Assistant assigned from the District.

To improve the quality of the Village Fund's financial reports, the placement of apparatus according to the educational background, providing a regular and planned training for the village apparatus in preparing the Village Fund's financial reports. The placement of the village apparatus based on the educational background, provide supportive facilities and infrastructure for work, and continuously monitor and evaluate to improve the work performances in all sides, such as physical, technical, and administrative works.

\section{References}

[1] Peraturan Pemerintah Republik Indonesia Nomor 71 Tahun 2010 Tentang Standar Akuntansi Pemerintahan, no. 1. 2010, pp. 1-5.

[2] Undang-Undang Nomor 6 Tahun 2014 Tentang Desa, no. 1. Indonesia, 2014, p. 2.

[3] Kementrian Keuangan Republik Indonesia, Buku Saku Dana Desa. Jakarta: Kementrian Keuangan RI, 2018.

[4] A. Solong, Manajemen Pengembangan Sumber Daya Manusia Menunjang Kinerja Aparatur Berkualitas. Yogyakarta: Deepublish, 2020.

[5] Mary Ann Von Glinow and S. McShane, Organizational Behaviour. New York: Mc Graw Hill Education, 2008.

[6] H. Umar, S. Usman, and R. B. R. Purba, "The influence of internal control and competence of human resources on village fund management and the implications on the quality of village financial reports," Int. J. Civ. Eng. Technol., 2018.

[7] K. Thenikusuma and N. Muis, "The Effect of Implementation Regional Financial Accounting System, Human Resource Competency and Infrastructure Facilities to the Quality of Financial Report," SSRN Electron. J., 2019, doi: 10.2139/ssrn.3313401.

[8] H. Setiyawati and D. Iskandar, "Importance of internal accountants' competence in shaping good quality financial reporting in local governments in Indonesia,” Int. J. Innov. Creat. Chang., 2020.

[9] H. N. Tambingon, W. Yadiati, and C. L. Kewo, "Determinant factors influencing the quality of financial reporting local government in Indonesia," Int. J. Econ. Financ. Issues, 2018.

[10] T. Silalahi and S. Sinambela, "Determinants of Financial Report Accountability, and It'S Implication on Financial Report Quality an Empirical Study of Financial Report Statement in North Sumatra Province, Indonesia,” Int. J. Econ. Commer. Manag. United Kingdom, 2017.

[11] S. Marina Palimbong, Y. Rura, and A. Tawakkal, "The Effect Of Competence of Human Resources and The Use of Information Technology on The Quality of Finacial Report with Internal Control System and Organizational Commitment as Moderation Variable," Int. J. Adv. Res., 2018, doi: 10.21474/ijar01/8168.

[12] M. Busro, Teori-teori Sumber Daya Manusia. Jakarta: Prenadamedia, 2018.

[13] E. Sutrisno, Manajemen Sumber Daya Manusia. Jakarta: Kencana, 2017.

[14] Hamsani, Organizational Citizenship Behavior di Bank Syariah. Surabaya: Scopindo Media Pustaka, 2020.

[15] E. S. Kusumaputri, Komitmen pada Perubahan Organisasi (Perubahan Organisasi dalam Perspektif Islam dan Psikologi). Yogyakarta: Deepublish, 2018. 
[16] F. Mustarida, S. Purba, Y. B. Setiawan, and A. Rumondang, Service Management. Jakarta: Yayasan Kita Menulis, 2020.

[17] H. Kertahadi, R. U. Sinaga, M. Syamsul, S. V. Siregar, and E. T. Wahyuni, Akuntansi Keuangan berdasarkan SAK berbasis IFRS. Jakarta: IAI, 2019.

[18] S. Sululing, Akuntansi Desa : Teori dan Praktek. Purwokerto: CV IRDH, 2018.

[19] Nurlis and W. Yadiati, "The Influence of Internal Control Effectiveness , Information Technology Utilization and Human Resources Competence on Local Government Financial Reporting Quality ( Survey on SKPD Banten Provincial Government and Serang City ),” Res. J. Financ. Account., vol. 8, no. 12, pp. 111-124, 2017, [Online]. Available: www.iiste.org.

[20] C. I. P. Shintia and N. M. A. Erawati, "Pengaruh Kualitas SDM, Pemanfaatan Sistem Informasi, Pengendalian Intern dan Komitmen Organisasi Pada Kualitas Laporan Keuangan," E-Jurnal Akunt., 2017, doi: 10.24843/eja.2017.v21.i02.p12.

[21] F. Lasmara and S. Rahayu, "Pengaruh Kompetensi Sumberdaya Manusia, Perangkat Pendukung Dan Peran Auditor Internal Terhadap Kualitas Laporan Keuangan Pemerintah Daerah Kabupaten Kerinci,” J. Perspekt. Pembiayaan dan Pembang. Drh., vol. 3, no. 4, pp. 231-242, 2016.

[22] D. Darwanis, "Effect of Professionalism, Competence, Knowledge of Financial Management, And Intensity Guidance Apparatus Inspectorate for Quality of Financial Statements (Study on Inspectorate Regencies/Cities in Aceh)," Brand. Broad Res. Accounting, Negot. Distrib., vol. 7, no. 1 , pp. 32-40, 2016.

[23] I. W. Karsan and I. G. N. Agung, "Pengaruh Efektivitas Penerapan Sap, Kompetensi Sdm, Dan Spi Pada Kualitas Laporan Keuangan Pemerintah Kabupaten Bangli," E-Jurnal Akunt., vol. 21 , pp. 643-670, 2017.

[24] T. M. Agung and . G., "Analisis Faktor-Faktor yang Mempengaruhi Kualitas Laporan Keuangan Pemerintah Daerah Kabupaten Karangasem," E-Jurnal Akunt., 2018, doi: 10.24843/eja.2018.v23.i02.p17.

[25] H. Setiyawati, "The effect of Internal Accountants' Competence, Managers' Commitment to Organizations and the Implementation of the Internal Control System on the Quality of Financial Reporting,” Int. J. Bus. Manag. Invent. ISSN, 2013.

[26] L. Hertati, "Competence of Human Resources, The Benefits of Information Technology on Value of Financial Reporting in Indonesia," Res. J. Financ. Account., 2015.

[27] F. F. Nasution, T. Supriana, and M. L. Dalimunthe, "The Influence of Competency of Human Resources, Implementation of Financial Application, and Implementation of Government Accounting Standard on Financial Statement Quality with Organizational Commitment as Moderating Variable,” Int. J. Public Budgeting. Account. Financ., 2018.

[28] D. Indriasih, "The Effect of Government Apparatus Competence and the Effectiveness of Government Internal Control Toward the Quality of Financial Reporting in Local Government," Res. J. Financ. Account., 2014.

[29] N. Nirwana and H. Haliah, "Determinant factor of the quality of financial statements and performance of the government by adding contextual factors," Asian J. Account. Res., 2018, doi: 10.1108/ajar-06-2018-0014.

[30] L. Widari and Sutrisno, "Pengaruh Sistem Pengendalian Internal Pemerintah dan Komitmen Organisasi Terhadap Kualitas Laporan Keuangan Daerah,” J. Ilm. Ilmu Ekon., 2017.

[31] Y. Dodopo, J. Sondakh, and J. Tinangon, "Pengaruh Komitmen Organisasi, Pengendalian Intern Akuntansi, Peran Internal Audit, Pendidikan, Dan Kualitas Pelatihan Terhadap Keterandalan Laporan Keuangan Pada Skpd Pemerintah Kabupaten Halmahera Utara," J. Ris. Akunt. Dan Audit. "Goodwill," vol. 8, no. 1, 2017, doi: 10.35800/jjs.v8i1.15306.

[32] I. B. P. Astika and G. W. Yasa, "Kemampuan Komitmen Organisasi Memoderasi Kompetensi Pejabat Penatausahaan Keuangan dan SPI Pada Kualitas Laporan Keuangan Kota Denpasar," E-Jurnal Akunt., 2018, doi: 10.24843/EJA.2018.v22.i01.p12.

[33] V. M. Pranata, "Pengaruh Pengendalian Internal dan Komitmen Organisasi Terhadap Kualitas Pelaporan Keuangan ( Survei pada Perusahaan Tekstil di Kota Bandung dan Sekitarnya )," JAFTA, vol. 1, no. 1, pp. 15-30, 2019, [Online]. Available: http://journal.maranatha.edu/Jafta. 
[34] S. Oktavia and S. Rahayu, "Pengaruh Kompetensi Sumber Daya Manusia, Komitmen Organisasi Dan Sistem Akuntansi Keuangan Daerah Terhadap Kualitas Laporan Keuangan Daerah,” eProceedings Manag., vol. 6, no. 1, pp. 652-659, 2019.

[35] U. Sekaran and R. Bougie, Metodologi Penelitian untuk Bisnis, Edisi 6 Bu. Jakarta: Salemba Empat, 2017.

[36] I. Ghozali, Mediasi dan Moderasi dalam Analisis Statistik. Semarang: Yoga Pratama, 2019.

[37] N. Fitriana and J. Hoesada, "The Effect of Asset Management, Implementation of Internal Control over Financial Reporting (ICOFR), and Organizational Commitment on Quality of Financial Reporting (Survey at Ministry of Marine Affairs of Fisheries Republic Indonesia), Sch. Bull., 2019, doi: 10.36348/sb.2019.v05i10.001. 